\title{
Effect of Crop Pruning on Sclerotinia Blight of Peanut
}

\author{
J. E. Bailey, Professor, and P. D. Brune, Research Assistant, Department of Plant Pathology, North Carolina State \\ University, Raleigh 27695-7617
}

\begin{abstract}
Bailey, J. E., and Brune, P. D. 1997. Effect of crop pruning on Sclerotinia blight of peanut. Plant Dis. 81:990-995.

Sclerotinia blight of peanut, incited by Sclerotinia minor, causes serious losses when cool, moist conditions prevail in the plant canopy. The effects of altering canopy structure by pruning were investigated in this study. Disease incidence was used to calculate area under the disease progress curve (AUDPC) for field plots receiving various shoot-pruning treatments. In 1990, pruned plots and iprodione-sprayed plots did not differ in AUDPC, but pruned plots produced higher yields. Disease levels and yield of July top-pruned plants did not differ from those of August top-pruned plants. Pruning tops and sides in August reduced yields compared to pruning tops and sides in July, even though August pruning produced lower AUDPC. Without fungicide treatment, the 1991 pruned plots had less disease than nonpruned plots, although yields did not differ significantly. Pruned plots treated with fungicides for control of Sclerotinia blight had less disease than nonpruned plots treated with these fungicides, but there were no differences in yield. Pruning peanut canopies to alter microclimate or enhance fungicide penetration may reduce disease and increase yield when $S$. minor damage is yield limiting.
\end{abstract}

Sclerotinia minor Jagger was first observed to infect peanut (Arachis hypogaea L.) in Virginia in 1971 (20), and was reported subsequently in North Carolina (20), Oklahoma (26), and Texas (24). Under environmental conditions favorable to disease development, Sclerotinia blight can result in yield losses of 10 to $50 \%$ (19).

Eruptively germinating sclerotia of $S$. minor on or near the soil surface initiate infection directly $(4,26)$. Usually, disease development is associated with relatively cool temperatures and high relative humidity or rainfall. Dow et al. (9) reported optimal myceliogenic germination of sclerotia at 20 to $25^{\circ} \mathrm{C}$. Imolehin et al. (15) observed germination of sclerotia between 6 and $30^{\circ} \mathrm{C}$, with an optimum at $18^{\circ} \mathrm{C}$; infection of lettuce tissues was most efficient at 12 to $24^{\circ} \mathrm{C}$. Studies with S. sclerotiorum demonstrated that a tissue wetness period of 48 to $72 \mathrm{~h}$ was necessary before invasion of tissue occurred $(1,27)$. However, Dow et al. (9) found that S. minor infected peanut tissue as long as relative humidity was greater than $94 \%$.

Newton and Sequeira (18) and Hawthorne (14) noticed that incidence of dis-

Corresponding author: J. E. Bailey

E-mail: jack_bailey@ncsu.edu

Mention of trade name or proprietary product does not constitute a guaranty or warranty of the product named and does not imply approval to the exclusion of other products that also may be available.

Accepted for publication 15 May 1997.

Publication no. D-1997-0721-01R

(C) 1997 The American Phytopathological Society ease caused by $S$. minor was less on lettuce genotypes with erect growth habits which allow the soil to warm up and dry. In screening peanut genotypes for resistance to $S$. minor, Coffelt and Porter (7) found a type of resistance that was correlated with an open canopy, and considered the mechanism of this resistance to be disease escape. Chappell et al. (6) showed that plant growth habit was an important contributor to field resistance of peanut to $S$. minor.

Mechanical modification of the canopy to alter the microclimate and prevent or abate disease has been examined in several pathosystems. Botrytis bunch rot of grape can be suppressed by removal of leaves from around flower clusters (12). This reduction in disease was related to four different microclimate parameters, with wind speed being the most important (11). Dry beans grown on trellises had increased yield and decreased disease incidence caused by $S$. sclerotiorum compared to non-trellised beans (8). Backman et al. (3) discovered that clipping vertical branches of peanut canopies reduced damage caused by Sclerotium rolfsii, presumably because an intact canopy maintained a more humid environment. Damage by $S$. rolfsii was enhanced by higher soil moisture levels in peanut stands (22).

Dow et al. (10) were able to create a more open canopy by thinning stands of peanut after blossom initiation, which lowered Sclerotinia blight severity and reduced lesion length compared to non-thinned stands. They attributed these reductions to lower relative humidity and lower soil moisture in the thinned plots. However, thinning established stands reduced yields.
Investigations of the effect of canopy pruning on peanut plants are reported in the literature. Turner (25) demonstrated that peanut plants could recover from pruning early (65 days after planting) as long as terminal shoots were left intact. Also, yield reductions from late pruning (98 days after planting) could be prevented by removing terminal shoots, presumably because removing them prevented plant energy resources from being used for additional shoot growth. However, new foliage growth from areas of the plant located below the terminal portion of the shoots has been observed (Bailey, unpublished data). Boote et al. (5) found that artificial removal of leaves from upper portions of the canopy had more negative effects than leaf removal from middle or lower areas. They attributed this to possibly decreased photosynthetic efficiency at lower levels in the canopy. However, Jones et al. (16) found photosynthetic activity increased after an initial decrease following leaf removal. They observed that older leaves, which are shaded by upper leaves, have a decreased rate of photosynthesis, but these older leaves presumably adapt to higher light intensity, increasing rates of photosynthesis over time. Photosynthetic recovery from leaf removal decreased with increasing plant age (16).

The objective of this study was to evaluate the effect of crop pruning on Sclerotinia blight management and yield of peanut.

\section{MATERIALS AND METHODS}

Peanut cultivar NC 7 was used in these experiments because it constituted the highest percentage of peanuts planted in North Carolina at the time of this research and is very susceptible to $S$. minor. Tests were conducted in Gates County, North Carolina in a commercial grower's field with a history of Sclerotinia blight. Standard crop husbandry practices as recommended by the North Carolina Cooperative Extension Service were used in test plots for 1990 and 1991, including a seeding rate of approximately $129 \mathrm{~kg} / \mathrm{ha}$. Rainfall was not supplemented by irrigation in either year of the study.

1990 field tests. Each plot consisted of four rows, $15.2 \mathrm{~m}$ long and $0.9 \mathrm{~m}$ apart. The experiment included eight treatments with three replications arranged in a randomized complete block design (RCBD). Iprodione (Rovral 50WP, Rhone Poulenc Ag Co., Research Triangle Park, NC) was applied to some plots to control S. minor at 
the rate of $1.12 \mathrm{~kg}$ a.i./ha on $17 \mathrm{July,} 14$ August, and 11 September with three 8008LP nozzles per row in a $45.72 \mathrm{~cm}$ band, using 151.4 liters of water/ha and $275.5 \mathrm{kPa}$ pressure. A string weed trimmer was used to prune plants. Treatments included pruning tops, sides, or both top and sides of plants on 17 July or on 16 August. Approximately $38 \%$ of plant height $(9.5$ $\mathrm{cm})$ was removed in July $(15.2 \mathrm{~cm}$ height remained), or $51 \%$ of height $(17.7 \mathrm{~cm})$ in August (17 cm remained). Side pruning removed approximately $30 \%$ total plant width $(18 \mathrm{~cm})$ in July $(41.2 \mathrm{~cm}$ width remained), or $34.5 \%(30.1 \mathrm{~cm})$ in August $(57.2 \mathrm{~cm}$ remained). Only the two inside rows of each plot were pruned; the outer rows on either side of the plot were borders. Plant debris created by the pruning were left in the plot. Plots receiving neither pruning nor iprodione served as nontreated controls.

Chlorothalonil (Bravo 6F, ISK Biotech Corp., Mentor, $\mathrm{OH}$ ) was applied biweekly $(2.2 \mathrm{~kg} / \mathrm{ha})$ to all plots for control of peanut early leaf spot (Cercospora arachidicola). Incidence of Sclerotinia blight was determined by counting the number of disease foci in the two center rows of each plot. A disease focus was defined as the presence of damage caused by $S$. minor on stems in each $30.5-\mathrm{cm}$ section of a row. If more than one stem in each section exhibited the presence of the pathogen (mycelium or sclerotia) or typical lesions, that section was considered to be a single focus, thus taking into account fungal spread from one stem to another in the same section. Data collection began on 17 July, when foliage of peanut plants in adjacent rows was an average of $30.5 \mathrm{~cm}$ apart. Assessments were made on 17 July, 16 and 29 August, 10 September, and 1 October 1990. Area under the disease progress curve (AUDPC) values were calculated for each treatment (21).

A standard analysis of variance for a RCBD was performed on both AUDPC and yield data. The treatment mean square was split into seven single degree of freedom contrasts (Table 1).

1991 field tests. Top pruning in July was the only treatment tested in 1991, because it was efficacious in 1990 and because it was the easiest to implement. The four replicate plots per treatment consisted of four rows $12.2 \mathrm{~m}$ long and $0.9 \mathrm{~m}$ apart. Treatments consisted of pruning tops of plants or no pruning; cupric hydroxide (Kocide 404 S, Griffin Corp., Valdosta, GA) or chlorothalonil (Bravo 6 F, ISK Biotech Corp.) to control early leaf spot; and iprodione (Rovral 50WP, Rhone Poulenc Ag Co.), fluazinam (ASC 66825 50WP, ISK Biotech Corp.) or no sprays for Sclerotinia blight control. All combinations of these treatments were employed to create a 2 by 2 by 3 factorial treatment design arranged in a RCBD. Fungicide applications were made with three hollow cone (T-Jet Tx 10) nozzles per row with approximately 140.48 liters of water per hectare and $275.5 \mathrm{kPa}$ pressure. Iprodione $(0.87 \mathrm{~kg}$ a.i./ha) and fluazinam $(0.22 \mathrm{~kg}$ a.i./ha) were applied on 17 July and 23 August. Chlorothalonil $(0.95 \mathrm{~kg}$ a.i./ha) or cupric hydroxide $(0.94$ $\mathrm{kg}$ metallic copper/ha and $0.77 \mathrm{~kg}$ sulfur/ha) was applied on 27 June, 10 and 24 July, 23 August, and 3 and 12 September. Pruning was carried out when approximately $30 \mathrm{~cm}$ remained between foliage of adjacent rows. Because it was noted in 1990 that many disease foci had no actively growing hyphae, disease assessment was conducted similarly to that in 1990, except that only disease foci with actively growing mycelium were counted. Data were collected on 18 and 24 July; 6, 21, and 28 August; and 4 and 19 September 1991. AUDPC was calculated for the treatments (21) and yield data were taken at harvest.

Analysis of variance procedures were performed for the RCBD of the 1991 field test treatments. Treatment sums of squares were partitioned into main effects and interaction effects for pruning, leaf spot sprays, and sprays for Sclerotinia blight. Thirteen single degree of freedom contrasts also were calculated, including four spray $\times$ pruning interaction contrasts (Table 2 ).

Table 1. Contrasts for the 1990 field experiment investigating effect of canopy pruning on Sclerotinia blight of peanut

\begin{tabular}{lccc}
\hline Contrast & df & $\begin{array}{c}\text { Area under disease } \\
\text { progress curve } \boldsymbol{P}>\boldsymbol{F}\end{array}$ & $\begin{array}{c}\text { Yield (kg/ha) } \\
\boldsymbol{P}>\boldsymbol{F}\end{array}$ \\
\hline $1 \quad$ Control $^{\text {a }}$ vs. iprodione & & 0.038 & 0.0002 \\
$2 \quad$ Pruned $^{\mathrm{b}}$ vs. iprodione & 1 & 0.39 & 0.011 \\
$\begin{array}{l}\text { (Pruning position) } \\
3 \quad \text { Top vs. side }\end{array}$ & 1 & & \\
$4 \quad$ Top vs. top and side & 1 & 0.007 & 0.22 \\
(Month within pruning position) & $(3)$ & 0.002 & 0.44 \\
$5 \quad$ July top vs. August top & 1 & & \\
$6 \quad$ July side vs. August side & 1 & 0.70 & 0.58 \\
$7 \quad$ July top and side vs. August top and side & 1 & 0.029 & 0.055 \\
\hline
\end{tabular}

${ }^{a}$ Control treatments received neither iprodione nor pruning.

${ }^{\mathrm{b}}$ Iprodione was applied three times $(1.12 \mathrm{~kg}$ a.i./ha) during the growing season to control Sclerotinia blight.

${ }^{\mathrm{c}}$ Pruning involved removing the tops, sides, or both tops and sides of the plant canopy in either July or August.

Table 2. Contrasts for the 1991 field experiment studying effects of canopy pruning on Sclerotinia blight of peanut

\begin{tabular}{|c|c|c|c|}
\hline Contrast & df & $\begin{array}{c}\text { Area under } \\
\text { disease progress } \\
\text { curve } P>F\end{array}$ & $\begin{array}{l}\text { Yield (kg/ha) } \\
\quad P>F\end{array}$ \\
\hline 1 Pruned vs. nonpruned $^{\mathrm{a}}$ & 1 & 0.0001 & 0.071 \\
\hline 2 Chlorothalonil vs. cupric hydroxide ${ }^{b}$ & 1 & 0.039 & 0.058 \\
\hline $\begin{array}{l}3 \text { Pruned-chlorothalonil vs. nonpruned- } \\
\text { chlorothalonil }\end{array}$ & 1 & 0.0005 & 0.009 \\
\hline$(\text { Spray })^{\mathrm{c}}$ & (2) & & \\
\hline 4 Spray vs. none & 1 & 0.87 & 0.22 \\
\hline 5 Iprodione vs. fluazinam & 1 & 0.034 & 0.027 \\
\hline$($ Spray $\times$ pruning) & (2) & & \\
\hline 6 Prune-sprayed vs. nonpruned sprayed & 1 & 0.0001 & 0.22 \\
\hline $\begin{array}{l}\text { Pruned-nonsprayed vs. nonpruned- } \\
\text { nonsprayed }\end{array}$ & $1^{\mathrm{d}}$ & 0.0014 & 0.15 \\
\hline 8 Pruned-fluazinam vs. nonpruned fluazinam & $1^{\mathrm{d}}$ & 0.0001 & 0.44 \\
\hline 9 Pruned-iprodione vs. nonpruned-iprodione & $1^{\mathrm{d}}$ & 0.0015 & 0.34 \\
\hline$($ Spray $\times$ leafspot $)$ & (2) & & \\
\hline $\begin{array}{l}10 \text { Chlorothalonil-iprodione vs. cupric } \\
\text { hydroxide-iprodione }\end{array}$ & 1 & 0.95 & 0.55 \\
\hline $\begin{array}{l}11 \text { Chlorothalonil-fluazinam vs. cupric } \\
\text { hydroxide-fluazinam }\end{array}$ & 1 & 0.0014 & 0.088 \\
\hline$($ Spray $\times$ prune $\times$ leafspot $)$ & (2) & & \\
\hline $\begin{array}{l}12 \text { Pruned-chlorothalonil-iprodione vs. } \\
\text { nonpruned-chlorothalonil-iprodione }\end{array}$ & 1 & 0.085 & 0.24 \\
\hline $\begin{array}{l}12 \text { Pruned-chlorothalonil vs. nonpruned- } \\
\text { chlorothalonil-iprodione }\end{array}$ & 1 & 0.034 & 0.25 \\
\hline
\end{tabular}

${ }^{a}$ Foliage from tops of plants was removed with a string weed trimmer, or foliage was left intact.

${ }^{b}$ Leafspot treatments consisted of fungicide sprays of chlorothalonil, cupric hydroxide, or no applications for control of peanut leafspots.

${ }^{\mathrm{c}}$ Spray treatments refer to application of iprodione, fluazinam, or no fungicides for Sclerotinia blight control.

${ }^{\mathrm{d}}$ Significance of effects of these contrasts were determined by Bonferroni $t$ test to protect against making a type I error. 
Bonferroni $t$ tests were used in order to protect against making a type I error (17).

A second, smaller pruning experiment also was carried out in 1991 in the same field. This study consisted of two treatments: pruning the top of plants and no pruning. A RCBD with four replications was employed. chlorothalonil was applied biweekly as above, but no fungicide was applied to control Sclerotinia blight. Active disease foci per plot were counted on 18 and 24 July; 6, 21, and 28 August; and 4 and 19 September. A $t$ test was used to discern differences between the two treatments.

\section{RESULTS}

In 1990 adequate rains fell throughout the season (June to August rainfall total $=$ $27.9 \mathrm{~cm}$ ). The 1991 growing season had excessive rainfall which produced long wet periods (June to August rainfall total $=$
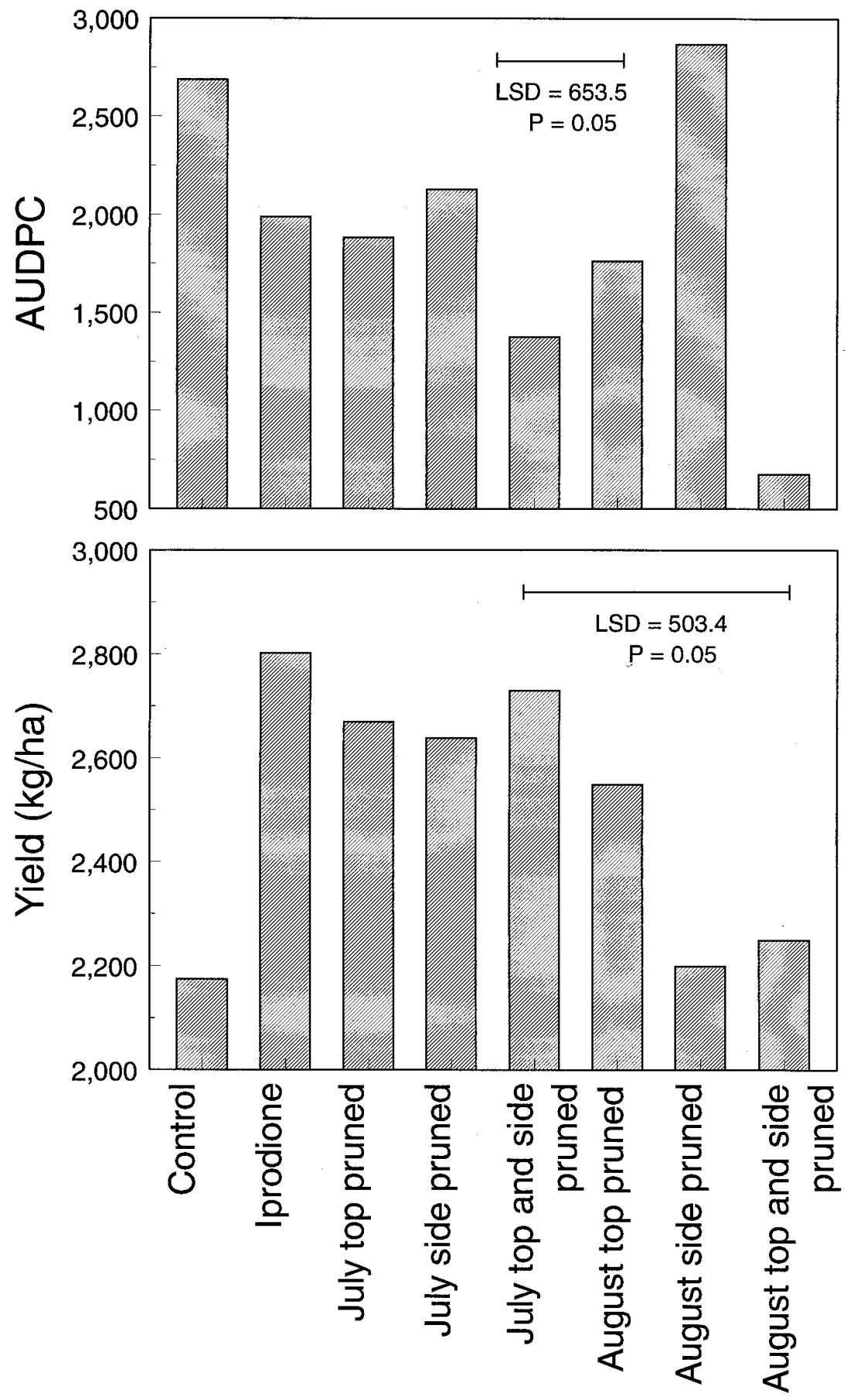

Fig. 1. Yield data and area under disease progress curve (AUDPC) values from the 1990 field experiment. Control treatment was neither pruned nor sprayed for Sclerotinia blight control. Iprodione treatment involved spraying iprodione at biweekly intervals. Pruning treatments included removal of tops, sides, or tops and sides of plants in either July or August. Least significant difference (LSD) was calculated for clarity of the figure. See Table 1 for results of partitioning treatment mean square into single degree of freedom contrasts.
$50.5 \mathrm{~cm})$. This encouraged plant growth and quickly created a dense canopy. Long periods of weather favorable to disease development occurred, even after pruning, due to excessive moisture.

1990 field test. Yield and AUDPC were not correlated $(R=-0.35, P=0.15)$. Use of iprodione resulted in lower AUDPC and higher yield than the control, i.e., nonpruned canopy without iprodione sprays (Fig. 1; Table 1). For most pruning treatments, AUDPC did not differ compared to the iprodione treatment, but the pruning treatments produced higher yields than the iprodione treatment. Plots receiving only side pruning in either July or August (Table 1) had higher AUDPC compared to plots where tops alone were pruned; however, there were no differences in yield. When pruning was carried out on both tops and sides, AUDPC was lower than that of pruning only tops, but there were no differences in yield (Table 1). No differences were detected in either AUDPC or yield among plots where tops were pruned in July or August (Table 1). Pruning sides in July reduced AUDPC compared to pruning sides in August, and yields were significantly different at $P=$ 0.06. Pruning the tops and sides in August produced a lower AUDPC than pruning tops and sides in July, but the August pruning also reduced yields.

1991 field tests. Yield and AUDPC were negatively correlated $(R=-0.61, P=$ $0.0001)$. There was a significant interaction between type of leafspot control spray and type of Sclerotinia blight control spray $(P$ $<0.03$ ) and a significant three-way interaction for pruning treatment, leafspot control spray, and Sclerotinia blight control spray $(P<0.009)$. Analysis did not show a significant leafspot control spray $\times$ pruning treatment interaction, so contrast comparisons were made using a Bonferroni $t$ test to protect against a type I error (17).

A much lower AUDPC resulted when the mean of all pruned treatments was compared to the mean of treatments without pruning, although there were no significant differences between overall means of yield (Fig. 2, Table 2). Treatments receiving chlorothalonil had lower AUDPC for Sclerotinia blight than those receiving cupric hydroxide for control of leaf spots, and yield differences were significant at $P$ $>0.06$. When pruned plots receiving chlorothalonil were compared to nonpruned treatments receiving chlorothalonil, pruned treatments had lower AUDPC and higher yield than nonpruned treatments (Table 2). No differences in AUDPC or yield resulted when all treatments with chemical sprays for Sclerotinia blight control were compared with all treatments that received no sprays for Sclerotinia blight control. Iprodione applications for Sclerotinia blight control (regardless of pruning treatment) resulted in a smaller AUDPC and a greater yield than use of 
fluazinam (Table 2). Plots that were pruned and sprayed for control of $S$. minor (iprodione or fluazinam) had lower AUDPC values than nonpruned plots that were sprayed with these chemicals, but there were no yield differences (Table 2). Pruned plots that were not sprayed for Sclerotinia blight control had a lower AUDPC than nonpruned plots that were not sprayed, but they did not differ in yield. Pruning and fluazinam application lowered AUDPC compared to fluazinam alone, but these two treatments did not differ in yield. Pruning combined with iprodione produced a lower AUDPC than iprodione, but there were no differences in yield.

No differences in AUDPC or yield were observed between chlorothalonil and cupric hydroxide for leaf spot control when both were in combination with iprodione (Table 2). When chlorothalonil and fluazinam were used together, AUDPC was lower than when cupric hydroxide was used in combination with fluazinam, but yields were not different. Pruned plots receiving chlorothalonil and iprodione were compared to nonpruned plots receiving these same chemicals, and no differences in AUDPC or yield were detected (Table 2). When pruned plots treated with only chlorothalonil were compared to nonpruned plots receiving applications of both chlorothalonil and iprodione, the pruned, chlorothalonil-treated plots had a lower AUDPC, but did not differ in yield from the chlorothalonil-iprodione treated plots.

In the second, smaller study of 1991, the pruned treatment had an AUDPC value of 285. This was significantly lower than the AUDPC value of 467 for nonpruned plots $(P=0.014)$. The pruned treatment had a yield of $3010 \mathrm{~kg} / \mathrm{ha}$ and the nonpruned treatment had a yield of $2741 \mathrm{~kg} / \mathrm{ha}$; differences between treatment yields were not significant.

\section{DISCUSSION}

In the 1990 field test, pruning controlled Sclerotinia blight as well as did the normal control practice of iprodione application to nonpruned plots. However, pruning (mean of all types of pruning) reduced yields below those of nonpruned plots receiving iprodione. If disease were the only factor affecting yield, then one would expect yield and AUDPC to be correlated, which did not occur. In 1991, only one position and one time of pruning was used, and yield and AUDPC were correlated. Different pruning regimes were included as treatments in 1990. This indicates that pruning position or timing may have negative effects on yield. Comparisons of the two pruning times and positions (top or side) suggested that August pruning may have a greater potential to be damaging to the plant. Several factors acting alone or in combination may have accounted for poor results from pruning in August. The greater amount of foliage removed, the cumulative effect of disease on plant health and fruitset prior to pruning, and the greater demand for photosynthate during the podfill/maturation phase of plant growth may have contributed to yield suppression.
Turner (25) suggested that yield reductions from late pruning (98 days after planting) would be lessened if terminal shoots were removed in order to prevent plant energy resources from being used for additional shoot growth. However, growth of new foliage on shoots from which the
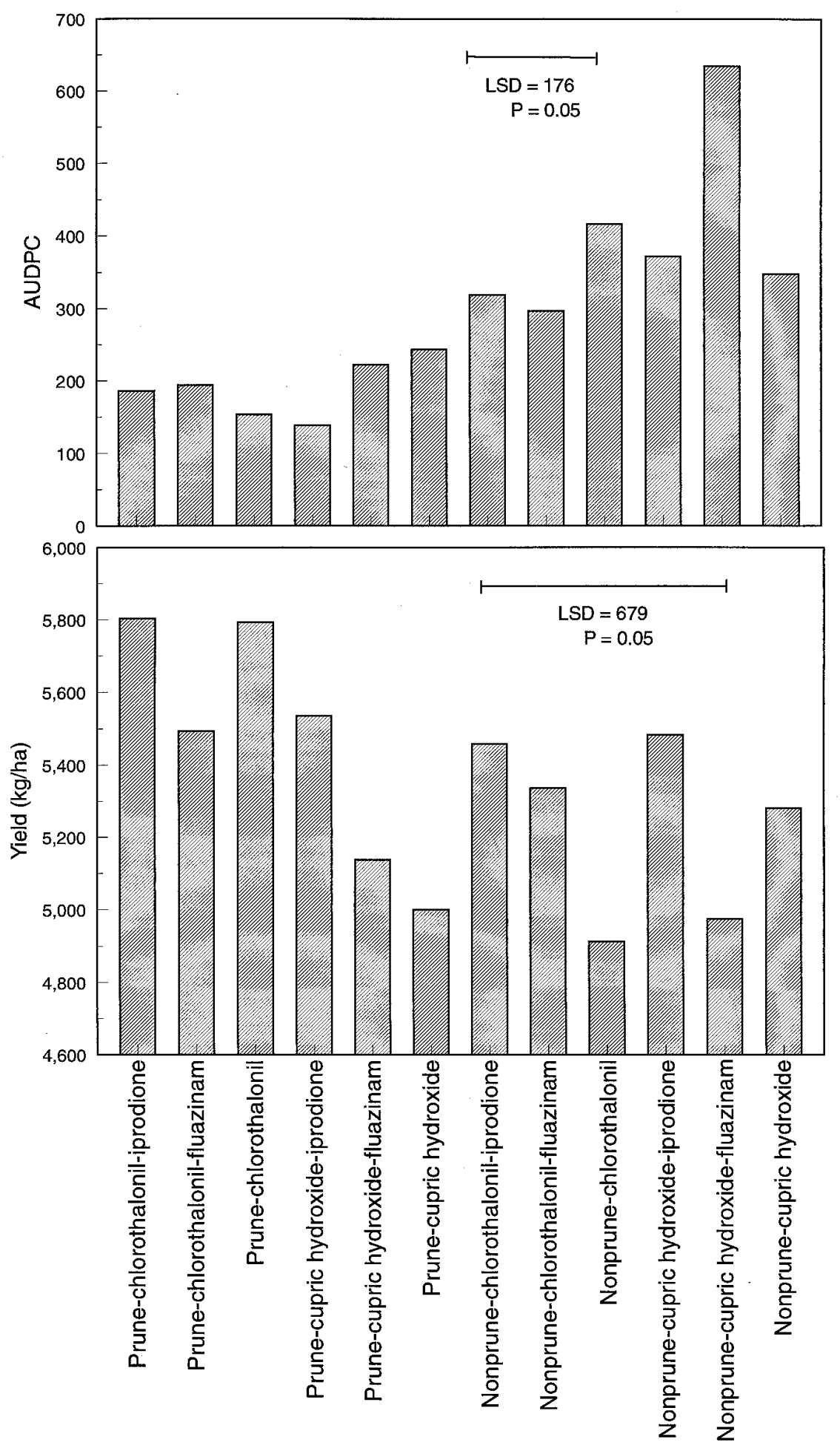

Fig. 2. Yield data and area under disease progress curve (AUDPC) values from the 1991 field experiment. Treatments consisted of combinations of pruning tops of plants or not pruning; using either chlorothalonil or cupric hydroxide for peanut leafspot control; and application of iprodione, fluazinam, or nothing for Sclerotinia blight control. This created a 2 by 2 by 3 experimental design. Least significant difference (LSD) was calculated for clarity of the figure. See Table 2 for results of partitioning treatment mean square into single degree of freedom contrasts. 
terminal portion had been pruned was observed; thus, photosynthates were still being used to support this additional growth, which may have led to the observed lower yields for late pruning.

If pruning in July was detrimental to yield, it was masked by increased yield due to lower disease severity. Although disease was suppressed by pruning tops and sides of plants in August compared to top and side pruning in July, August pruning was detrimental to yield (1990 test). Because top pruning resulted in lower AUDPC than side pruning treatments, only the less labor intensive pruning method-top pruningwas utilized for 1991 tests. This method of foliage removal is also practical because it can be implemented with rotary mowers commonly found on farms.

Foliar sprays of iprodione are recommended for Sclerotinia blight control in North Carolina. In general, pruning alone (1991 test) resulted in an AUDPC equal to that of iprodione sprays. These findings support the use of crop pruning as a possible alternative to the use of iprodione for Sclerotinia blight control.

In 1991, pruning alone reduced Sclerotinia blight incidence compared to plots which were not pruned, but there were no significant differences in yield. The lack of yield increase could have resulted from some detrimental effects to the plant due to pruning damage. It also is possible that the amount of disease control was not sufficient to result in measurable yield increases. It was noted that canopies of nonpruned plots had become more open by the end of the season due to $S$. minor-incited limb death, and rank vine growth caused the canopy to collapse. This more open canopy could have suppressed further disease development.

Pruning in combination with iprodione (1991 test) gave significantly better disease control than the use of iprodione on nonpruned plots. Highest yields resulted when iprodione-treated pruned plots were combined with chlorothalonil for leaf spot control. Pruning allowed for better fungicide coverage of the vines, a more easily controlled epidemic due to a less favorable environment, or both. Fluazinam is normally more active against $S$. minor than iprodione (23). However, in the 1991 test, iprodione resulted in better control of Sclerotinia blight than fluazinam. It is possible that fluazinam is less effective under extremely wet conditions due to a shortened half-life in the presence of excess moisture (2).

The effectiveness of pruning is dependent on when pruning is performed. It is likely that pruning will not be beneficial in very dry seasons. Conversely, excessive shoot growth may serve as the best indicator of the need for pruning. Monitoring environmental conditions favorable for Sclerotinia blight in the peanut canopy would be a less ambiguous, although less practical, method of determining when conditions are favorable for Sclerotinia blight development.

Chlorothalonil can enhance the severity of Sclerotinia blight by increasing the aggressiveness of the fungus (13), or possibly by controlling leaf spot and thereby increasing canopy density. Chlorothalonil applications also may be detrimental to $S$. minor antagonists. In the 1991 experiment, there was no evidence that use of chlorothalonil increased the severity of this disease. Chlorothalonil-treated plots had greater yields and/or lower AUDPC than cupric hydroxide-treated plots. There were no differences between chlorothalonil and cupric hydroxide treatments when they were used in conjunction with iprodione. When used with fluazinam, the AUDPC was lower for chlorothalonil than for cupric hydroxide-treated plots, but yields were not significantly higher.

Pruning contributed to lower incidence of Sclerotinia blight on peanut and can have a positive effect on yield if appropriately timed. Pruning may enhance fungicide activity by allowing better penetration into the canopy in conjunction with effects due to a microclimate which is less favorable for disease development. It is possible that pruning alone may serve as a practical disease management practice. Typical farm machinery can be used for pruning peanut vines, but additional work needs to be conducted to determine which type of implement is most appropriate for vine pruning. For example, a sickle mower would be more gentle and perhaps cause less mechanical damage to vines than a rotary-type mower.

Because the 1991 experiment was a variation of the 1990 investigation, consistency of results should be tested further. A method of determining when, whether, and how much foliage to remove is a necessary next step in making this a practical procedure. Possible genotype by pruning interactions also must be investigated. Effect of pruning on other diseases will also need to be investigated.

\section{ACKNOWLEDGMENTS}

We would like to thank Marcia L. Gumpertz for her guidance in statistical analysis and presentation of the data, and Carl Murphey for his assistance in maintaining the field studies.

\section{LITERATURE CITED}

1. Abawi, G. S., and Grogan, R. G. 1975. Source of primary inoculum and effects of temperature and moisture on infection of beans by Whetzelinia sclerotiorum. Phytopathology 65:300-309.

2. Anonymous. 1991. Technical data sheet: ASC-66825 Experimental Fungicide. ISK Biotech Corp. Mentor, OH. 44061-8000.

3. Backman, P. A., Rodriguez-Kabana, R., and Williams, J. C. 1975. The effect of peanut leafspot fungicides on the nontarget pathogen, Sclerotium rolfsii. Phytopathology 65:773776.

4. Beute, M. K., Porter, D. M., and Hadley, B. A. 1975. Sclerotinia blight of peanut in North
Carolina and Virginia and its chemical control. Plant Dis. Rep. 59:697-701.

5. Boote, K. J., Jones, J. W., Smerage, G. H., Barfield, C. S., and Berger, R. D. 1980. Photosynthesis of peanut canopies as affected by leafspot and artificial defoliation. Agron. J. 72:247-252.

6. Chappell II, G. F., Shew, B. B., Ferguson, J. M., and Beute, M. K. 1995. Mechanisms of resistance to Sclerotinia minor in selected peanut genotypes. Crop Sci. 35:692-696.

7. Coffelt, T. A., and Porter, D. M. 1982 Screening peanuts for resistance to Sclerotinia blight. Plant Dis. 66:385-387.

8. Coyne, D. P., Steadman, J. R., and Anderson, F. N. 1974. Effect of modified plant architecture of Great Northern dry bean varieties (Phaseolus vulgaris) on white mold severity, and components of yield. Plant Dis. Rep. 58:379-382.

9. Dow, R. L., Porter, D. W., and Powell, N. L. 1988. Effect of environmental factors on Sclerotinia minor and Sclerotinia blight of peanut. Phytopathology 78:672-676.

10. Dow, R. L., Powell, N. L., and Porter, D. W. 1988. Effects of modification of the plant canopy environment on Sclerotinia blight of peanut. Peanut Sci. 15:1-5.

11. English, J. T., Thomas, C. S., Marois, J. J., and Gubler, W. D. 1989. Microclimates of grapevine canopies associated with leaf removal and control of Botrytis bunch rot. Phytopathology 79:395-401.

12. Gubler, W. D. 1987. Control of Botrytis bunch rot of grape with canopy management. Plant Dis. 71:599-601.

13. Hau, F. C., and Beute, M. K. 1983. Effects of chlorothalonil on the virulence and physiology of a nontargeted pathogen, Sclerotinia minor. Phytopathology 73:475-479.

14. Hawthorne, B. T. 1974. Sclerotinia minor on lettuce: effect of plant growth on susceptibility to infection. N.Z. J. Agric. Res. 17:387392.

15. Imolehin, E. D., Grogan, R. G., and Duniway, J. M. 1980. Effect of temperature and moisture tension on growth, sclerotial production, germination, and infection by Sclerotinia minor. Phytopathology 70:1153-1157.

16. Jones, J. W., Barfield, C. S., Boote, K. J. Smerage, G. H., and Mangold, J. 1982. Photosynthetic recovery of peanuts to defoliation at various growth stages. Crop Sci. 22:741746.

17. Neter, J., and Wasserman, W. 1974. Applied linear statistical models. Richard D. Irwin, Inc.

18. Newton, H. C., and Sequeira, L. 1972. Possible sources of resistance in lettuce to Sclerotinia sclerotiorum. Plant Dis. Rep. 56:875878.

19. Porter, D. M. 1984. Sclerotinial blight. Pages 16-18 in: Compendium of Peanut Diseases. Porter, D. M., Smith, D. H., and RodriguezKabana, R., eds. The American Phytopathological Society, St. Paul, MN.

20. Porter, D. M., and Beute, M. K. 1974. Sclerotinia blight of peanuts. Phytopathology 64:263-264.

21. Shaner, G., and Finney, R. E. 1977. The effect of nitrogen on the expression of slow-mildewing resistance in Knox wheat. Phytopathology 67:1051-1056.

22. Shew, B. B., and Beute, M. K. 1984. Effects of crop management on the epidemiology of southern stem rot of peanut. Phytopathology 74:530-535.

23. Smith, F. D., Phipps, P. M., and Stipes, R. J. 1991. Agar plate, soil plate, and field evaluation of fluazinam and other fungicides for control of Sclerotinia minor on peanut. Plant Dis. 75:1138-1143.

24. Sturgeon, R. V. 1982. Peanut disease loss 
estimates for major peanut producing states in the United States for 1981. Proc. Am. Peanut Res. Educ. Soc. 14:86-87.

25. Turner, J. W. 1982. Effect of defoliation on yield of peanut (Arachis hypogaea). Queensl.
J. Agric. Anim. Sci. 39:183-185.

26. Wadsworth, D. F. 1979. Sclerotinia blight of peanuts in Oklahoma and occurrence of the sexual stage of the pathogen. Peanut Sci. 6:77-79.
27. Weiss, A. E., Kerr, E. D., and Steadman, J. R 1980. Temperature and moisture influences on development of white mold disease (Sclerotinia sclerotiorum) on Great Northern beans. Plant Dis. 64:757-759. 